\title{
Pediatrik femur diyafiz ve distal femur kırıkları
}

\author{
Pediatric femoral diaphysis and distal femoral fractures
}

\author{
Hasan Hilmi Muratlıํㅗ Eşref Selçuk ${ }^{2}$ \\ ${ }^{1}$ Marmara Üniversitesi Tıp Fakültesi, Pendik Eğitim ve Araştırma Hastanesi, Ortopedi ve Travmatoloji, İstanbul \\ 2Ürgüp Devlet Hastanesi, Ortopedi ve Travmatoloji, Nevşehir
}

Pediatrik femur diyafiz ve distal femur kırıkları; travma, patolojik kemik hastalıkları, tekrarlayan stresler veya çocuk istismarı sonucunda gerçekleşebilir. Tedavi seçeneklerinde çocuğun yaşı belirleyici olmakla beraber, hastanın kilosu, boyu, kırık paterni de dikkate alınmalıdır. Femur diyafiz kırıkları için ilk altı aylık dönemde Pavlik bandaj, altı ay ile beş yaş arası pelvipedal alçı kullanılır. Uzunluk olarak stabil 5-11 yaş ve 49 kilodan az hastalar fleksibl intramedüller çivi ile tedavi edilir. Stabil olmayan kırıklarda ise plak kullanılabilir. On bir yaşından büyük hastalar ise trokanterik girişli intramedüller çivi ile tedavi edilebilir. Distal femur kırıkları kaymamış ise konservatif olarak tedavi edilebilir. Kaymış kırıklarda ise kırığın durumuna göre eksternal fiksatör, perkütan pin tespiti ve alçılama veya açık redüksiyon-internal tespit uygulanır. Kaymış Salter-Harris Tip 1-2 kırıklar ve kaymamış Salter-Harris Tip 3-4 kırıklarda, kapalı redüksiyon internal tespit ile tedavi önerilir. Redükte edilemeyen Salter-Harris Tip 1-2 ve kaymış Salter-Harris Tip 3-4 kırıklar ise açık redüksiyon ve tespit ile tedavi edilmelidir. Fizisi ilgilendiren femur kırıklarında hasta yakından takip edilmeli, bacak uzunluk farkı ve açısal deformiteler not edilmelidir. Her tedavi şeklinde komplikasyonlar olma olasılığı mevcut olup, hasta yakınları bu konuda bilgilendirilmelidir.

Anahtar sözcükler: çocuk; femur; kırık; metafiz; fizis
Pediatric diaphyseal femur and distal femur fractures may occur due to trauma, pathological bone disease, stress fracture or child abuse. Age of the child is the primary factor while deciding treatment options. However, other factors such as patient's weight and height, fracture pattern and soft tissue should be taken into consideration. Diaphyseal femur fractures in patients younger than 6 months can be treated with spica cast or Pavlik harness. Fractures in patients from 6 months to 5 years can be treated with early spica cast. In children 5 years to 11 years with stable fracture and less than $49 \mathrm{~kg}$, flexible intramedullary nailing can be used. Plate may be needed in unstable fractures. Fractures of femur in children older than 11 years to skeletal maturity can be treated with trochanteric entry intramedullary nailing. Nondisplaced distal femur fractures can be treated conservatively. In displaced fractures, external fixator, percutanous fixation-cast, open reduction-internal fixation can be used according to fracture pattern and soft tissue condition. In displaced Salter-Harris type 1-2 fractures and for nondisplaced Salter-Harris type 3-4 fractures, closed reduction and percutaneous fixation is recommended. Open reduction and fixation is the suggested treatment model for unreducible Salter type 1-2 and displaced Salter-Harris type 3-4 fractures. Fractures related to physis should be closely monitored, limb length discrepancy and angular deformity should be noted in every visit. Patient and parents must be informed about the possible complications.

Key words: femur; fractures; children; metaphysis; physis

\section{FEMUR CISIM KIRIKLARI}

Zaman içerisinde toplumda meydana gelen değişiklikler ve sağlık hizmetlerine ulaşımdaki kolaylıklar, pediatrik kırık tedavisindeki gelişmelerle paralellik göstermiştir. Hastalar kısa sürede eski fonksiyonel durumlarına geri dönmek isterler. Bu dönüş sırasında da diğer kişilere bağımlı olarak yaşamak istemezler. Buna paralel olarak da zaman içerisinde cerrahi tedavilerin oranı artmıştır. ${ }^{[1-3]}$
Spor organizasyonlarının yaygınlaşması ve ders dışı aktivitelerin artmasıyla, tüm pediatrik kırıklarda olduğu gibi femur cisim kırıklarının da görülme sıklığı artmıştır. Femur cisim kırıkları bimodal dağılım gösterir, ilk olarak 2-3 yaş arasında ve ikinci olarak da adolesan evrede sıklıkla görülür. ${ }^{[4]}$ Düşük sosyoekonomik düzeydeki çocuklarda görülme sıklığı daha fazladır. ${ }^{[2]}$ İzole femur kırıkları yetişkinlere oranla daha sık görülür, ancak mortalitesi yetişkin hasta grubuna göre daha azdır.

- Illetişim adresi: Prof. Dr. Hasan Hilmi Muratlı, Marmara Üniversitesi Tıp Fakültesi, Pendik Eğitim ve Araştırma Hastanesi, Ortopedi ve Travmatoloji Anabilim Dalı, Fevzi Çakmak Mah. Muhsin Yazıcıoğlu Cad. No:10 Üst Kaynarca, Pendik, İstanbul Tel: 0505 - 2997709 e-posta: hasanmuratli@yahoo.com

- Geliș tarihi: 2 Subat 2019 Kabul tarihi: 2 Subat 2019 


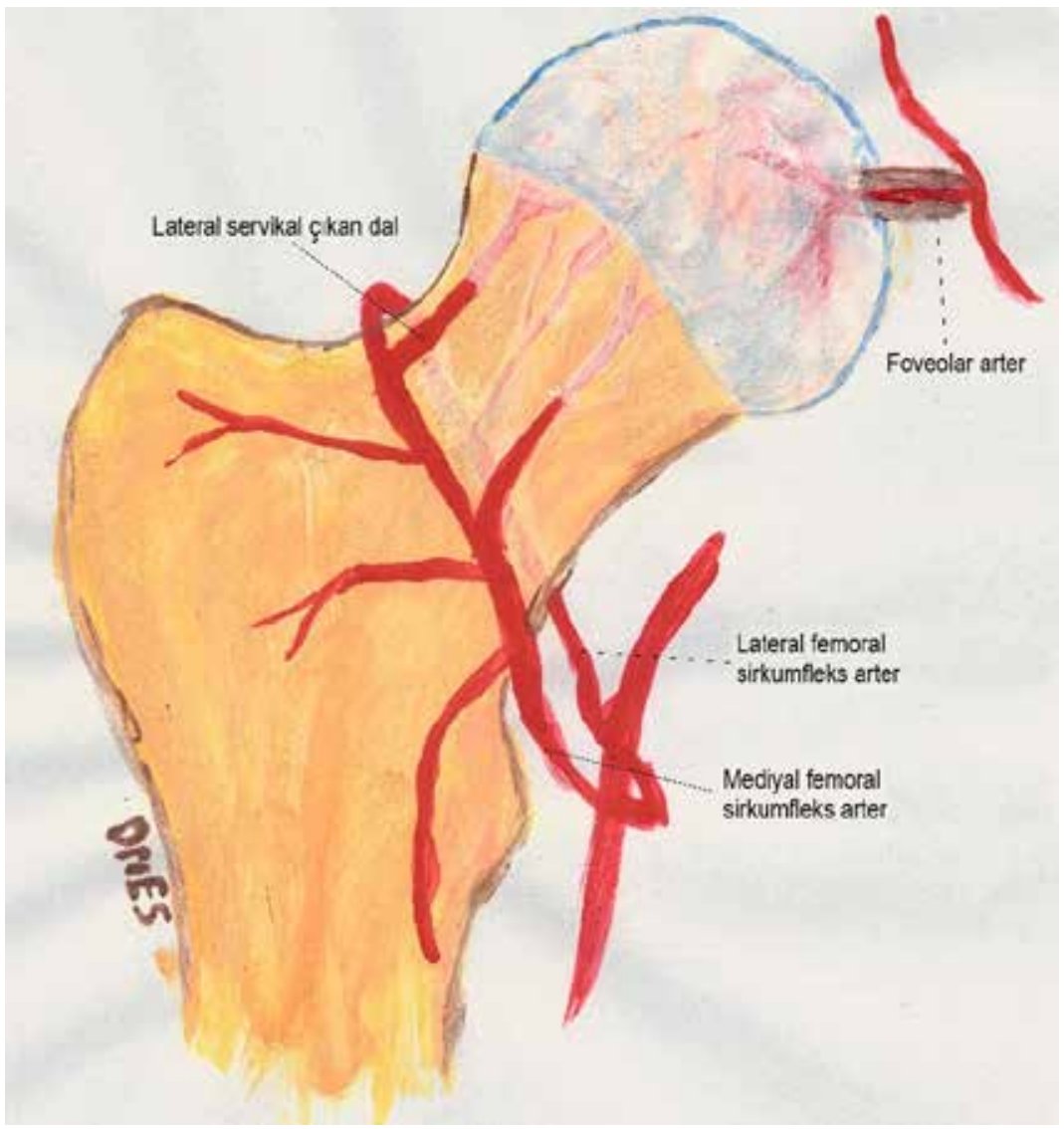

Şekil 1. Femur başının kanlanması (posteriordan görünüm).

Pediatrik yaş grubunda mortalite genellikle, eşlik eden yaralanmalar nedeniyle gerçekleşir. ${ }^{[5]}$

\section{Anatomi}

Femur, vücudumuzdaki en uzun ve en güçlü kemiktir. Tübüler cisim, hemisferik baş ve bikondiller distal kısımdan oluşur. Trokanter majör de tedavi sırasında dikkat edilmesi gereken yapılardan biridir. Lateral grafide femur başının posteriorunda kalır.

Erişkin yaşta femur, toplam boyun \%26'sını oluşturur. Distal büyüme plağı femur boyunun \%71'ine, proksimal büyüme plağı ise \%29'una katkı sağlar.

Femur, embriyonik hayatın 4. haftasında mezodermden köken alır. Sekizinci haftada primer ossifikasyon merkezi kemikleşmeye başlar ve 16 . haftada tüm femur ossifiye olur. Doğumda, sekonder ossifikasyon merkezlerinden sadece distal sekonder ossifikasyon merkezi vardır; diğerleri nadiren bulunur. Kıkırdak kitle üç farklı evrede gelişir: femur başında 5. ayda, trokanter majörde 3.-4. yılda, trokanter minörde 7.-9. yılda. Trokanter majör apofizinin proksimal femur gelişimindeki önemi büyüktür. Sekiz yaşından sonra bu ossifikasyon merkezinin femur boyun angülasyonunun üzerindeki etkisi azalır.

Femur cismi, endosteal ve periosteal kan akımına sahiptir. Derin femoral arterin bir veya iki nütrisyonel dalı femur cisminin endosteal dolaşımını ve korteksin $2 / 3$ iç kısmının kanlanmasını sağlar. ${ }^{[6]}$ Korteksin $1 / 3$ dış kısmı femoral ve derin femoral arterden çıkan iki dal tarafından sağlanır. Femur başının kanlanması ise mediyal femoral sirkumfleks arterin çıkan dalı tarafından (servikal lateral çıkan dal) sağlanır (Şekil 1). ${ }^{[7]} \mathrm{Bu}$ dal, femur başına giderken priformis fossa üzerinden geçer.

Çocukluk çağı boyunca kollodiyafizer açı ve anteversiyon açısı değişir. Kollodiyafizer açı $150^{\circ}$ 'den $130^{\circ}$ 'ye, anteversiyon açısı $40^{\circ}$ 'den $10^{\circ}$ 'ye düşer. ${ }^{[8]}$

\section{Yaralanma Mekanizması}

Pediatrik femur kırıkları genellikle yüksek enerjili trafik kazaları sonucunda meydana gelir. Bu kırıklar, travmanın yanı sıra çocuk istismarı, patolojik nedenler ve stres sendromları sonucu da oluşabilir. ${ }^{[3,9,10]}$ 


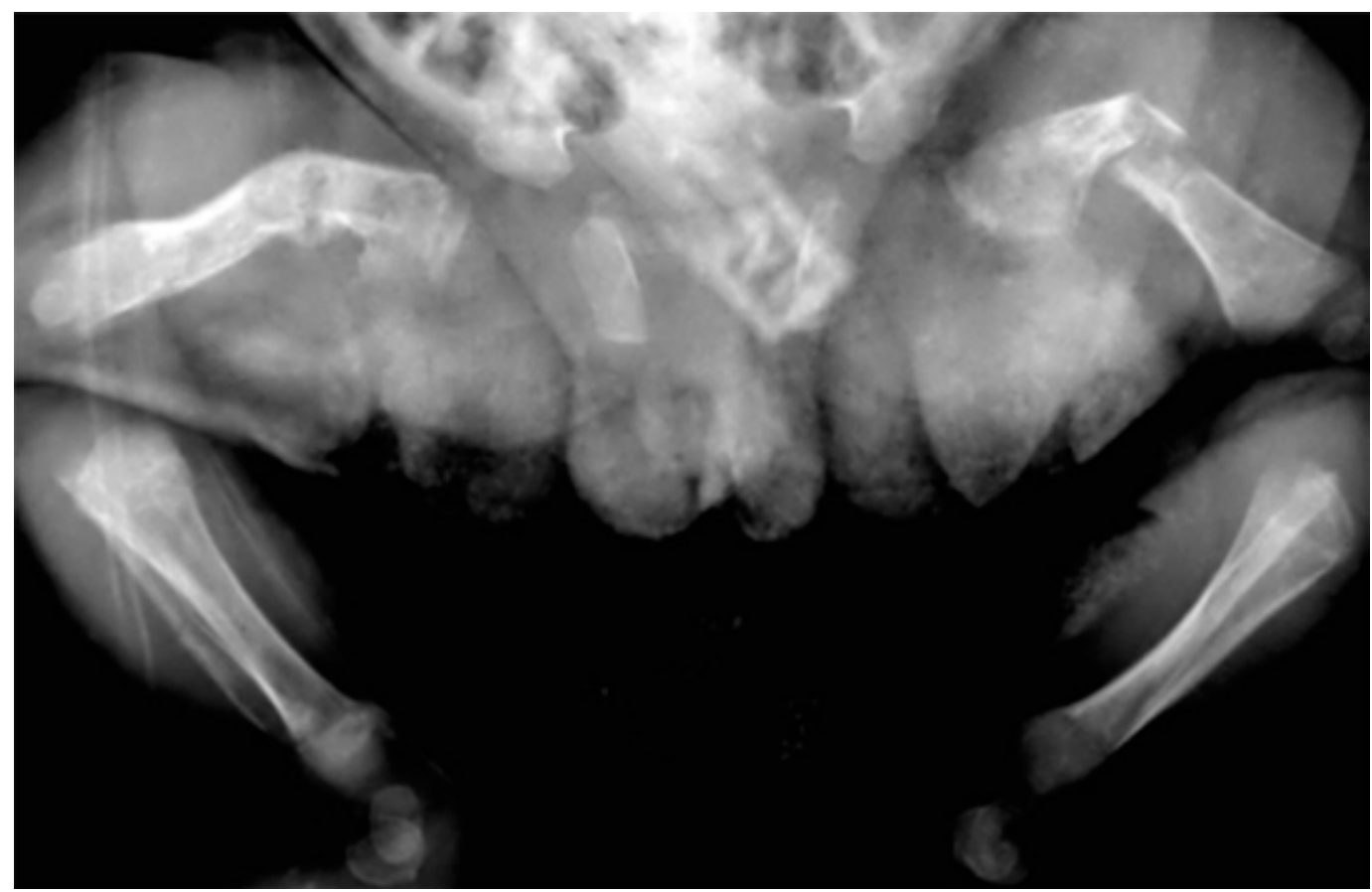

Şekil 2. Üç haftalık kız çocuğu sol femur cisim kırığı (osteogenezis imperfekta). Sağ taraftaki eski kırık hattına da dikkat.

Travma dışı femur cisim kırıklarına genellikle distal femur kırıkları da eşlik eder. Dört yaş altı femur kırıklarının \%30'u, yürüme çağı öncesi meydana gelen femur kırıklarının ise \%80'i çocuk istismarı sonucu gerçekleşmektedir. Yürüme çağından önce meydana gelen femur kırıklarında, farklı iyileşme evrelerinde olan ekimozlarda, yanıklarda ve çoklu kırıkların olduğu hastalarda çocuk istismarı akla gelmelidir. Üç yaşından küçük femur cisim kırı̆̆ı olan çocukların çocuk istismarı açısından değerlendirilmesi önerilir. ${ }^{[11]}$

Biyomekanik özelliklerin bozulduğu metabolik kemik hastalıkları, tümörler, materyal çıkarımları veya radyasyon maruziyeti sonucu da femur kırıkları gelişebilir (Şekil 2). ${ }^{[12]}$ Aşırı tekrar gerektiren hareketlerin olduğu egzersizlerde, kemik remodele olmakta başarısız olursa stres kırıkları meydana gelebilir. Genellikle kırık öncesi, hızlandırılmış bir egzersiz programı veya normalin dışında yoğunlaşmış bir aktivite söz konusudur. ${ }^{[13]}$

\section{Genel Yaklaşım}

Yaralanma mekanizmasını anlamada ve tedaviye şekil vermede, hastanın öyküsünün alınması önemlidir. Kırığın yüksek enerjili bir travma mı yoksa patolojik bir süreç sonucu mu olduğu bilgisi, tedavi sürecine etki edecektir. Şüpheli bir öykü, travma dışı nedenlerin veya çocuk istismarının araştııılmasını gerektirir. ${ }^{[10,12]}$
Fizik muayene, her zaman hastanın güvenini kazanmakla başlamalıdır. Hastanın güveni kazanıldıktan sonra dikkatli bir inceleme yapılmalıdır. Dikkati çeken deformite, şişlik, doku defekti varsa not alınmalıdır. Ardından yaralanma dışındaki alanlar dikkatlice palpe edilmeli ve varsa ikinci yaralanmalar açığa çıkarılmalıdır. Motor ve duyu muayenesi yapılmalı ve nabızlar kayıt edilmelidir. ${ }^{[14]}$ Yaralı ekstremite, sağlam ekstremite ile karşılaştırılmalıdır.

İpsilateral tibia kırı̆̆ının eşlik ettiği durumlarda (yüzen diz), vasküler muayeneye dikkat edilmelidir. Artan hematom, üzerinde trill palpe edilen şişlikler ve pulsatif kanamalar dikkatlice incelenmelidir. Acil serviste tarama testi olarak ayak bileği-kol indeksi (ankle-brachial index [ABI]) kullanılabilir. ABI'nın 0,9'dan düşük olması ek radyolojik görüntüleme ihtiyacı doğurur. ${ }^{[14]}$

Yaralı ekstremitenin muayenesi en son ve nazikçe yapılır. Cerrahi planlanan hastaların traksiyon ve redüksiyonları, yara yeri incelenmesi minimal düzeyde tutulmalıdır. ${ }^{[12]}$ Manipülasyonlar ve yara yeri değerlendirilmesi ameliyathanede yapılmalıdır. Ancak, yapılacak manipülasyonlarla hastanın ağrısı ve deformitesi azalacak ise, bunlar acil serviste de yapılabilir. Manevralar sırasında seri olarak nabız kontrolü yapılmalıdır.

Femur kırığı olan pediatrik hastada gelişen hipotansiyon, hipovolemi veya anemi, ileri araştırma gerektirir. 
Bu durum, neredeyse her zaman ek bir yaralanma sonucu gelişir. ${ }^{[15,16]}$ Yüksek enerjili trafik kazalarında femur kırığı, intraabdominal veya intratorasik yaralanma ve kraniyel yaralanmadan oluşan "Waddell triadı" akla gelmelidir. Yüksek enerjili yaralanmalarda, ileri travma yaşam desteği protokolleri uygulanır. Kırığa yönelik görüntüleme işlemlerine, hasta stabil olduktan sonra geçilir.

Pediatrik insidansı bilinmemekle birlikte, femur cisim kırıkları yüksek oranda intra-artiküler diz yaralanmaları ile birlikte görülür. Akut dönemde bağ ve kırkırdak hasarlarının değerlendirilmesi zor olsa da, ilerleyen süreçte bu gibi ek yaralanmalar için seri değerlendirmeler yapılmalıdır.

Pediatrik femur kırıkları için, kalça ve diz eklemini içine alan uyluk anterior-posterior (AP) ve lateral radyografi genellikle yeterlidir (Şekil 3). Birçok yazar, pediatrik femur kırığı sonrası stabilitenin değerlendirilmesi ve tedavi sonuçlarını tahmin etmek için traksiyon grafileri kullanılmasını önermektedir. Thompson ve ark. tarafından tanımlanan "teleskop testi" ile, $30 \mathrm{~mm}$ kısalık oluşan hastalarda tedavi sonrasında $25 \mathrm{~mm}$ kısalık gözlenme oranının 20 kat arttığı gösterilmiştir. ${ }^{[17]}$ Test yapılmadan ölçülen kısalık ile tedavi sonuçları arasında ise bir ilişki bulunamamıştır.

Tedavi sonrası aşırı kısalık oluşumunun yumuşak doku yaralanması ile ilişkili olduğu öne sürülmektedir. Öykü ve iyi bir fizik muayene ile hastada kısalık gelişip gelişmeyeceği hakkında bilgi sahibi olunabilir.

Bilgisayarlı tomografi (BT) periartiküler veya fiziyel yaralanmaları değerlendirmede yarar sağlar, ancak izole femur kırığında BT gerekli değildir. Kemik sintigrafisi şüpheli stres kırıklarında ve patolojik kırıklarda yararlıdır.

Manyetik rezonans (MR) görüntüleme, intra-artiküler patolojilerin görüntülenmesinde, stres kırıklarında, patolojik lezyonlarda, ipsilateral yaralanmaların olduğu epifiz, bağ ve meniskal yaralanmaların tanı ve tedavisinde katkı sağlar. Cisim kırı̆ıı iyileşen ancak dizinde ağrısı devam eden hastalarda tanısal amaçlı da kullanılmaktadır. ${ }^{[18]}$

\section{Sınıflama}

Genel, evrensel olarak kabul edilen bir pediatrik femur kırığı sınıflaması bulunmamaktadır. Ancak femur kırıkları; nedeni, yumuşak doku bütünlüğü, anatomisi ve kırık paterni değerlendirilerek sınıflandırılabilir. ${ }^{[12]}$

Yumuşak doku ve kalın periosteum, pediatrik kırıkların stabilitesinde önemli bir rol oynar. Bu, yaş ile ters orantılı olarak azalır. Aşıı yumuşak doku hasarının olduğu ve periosteal sıyrılmanın gerçekleştiği kırıklarda stabilitenin sağlanması daha zordur.

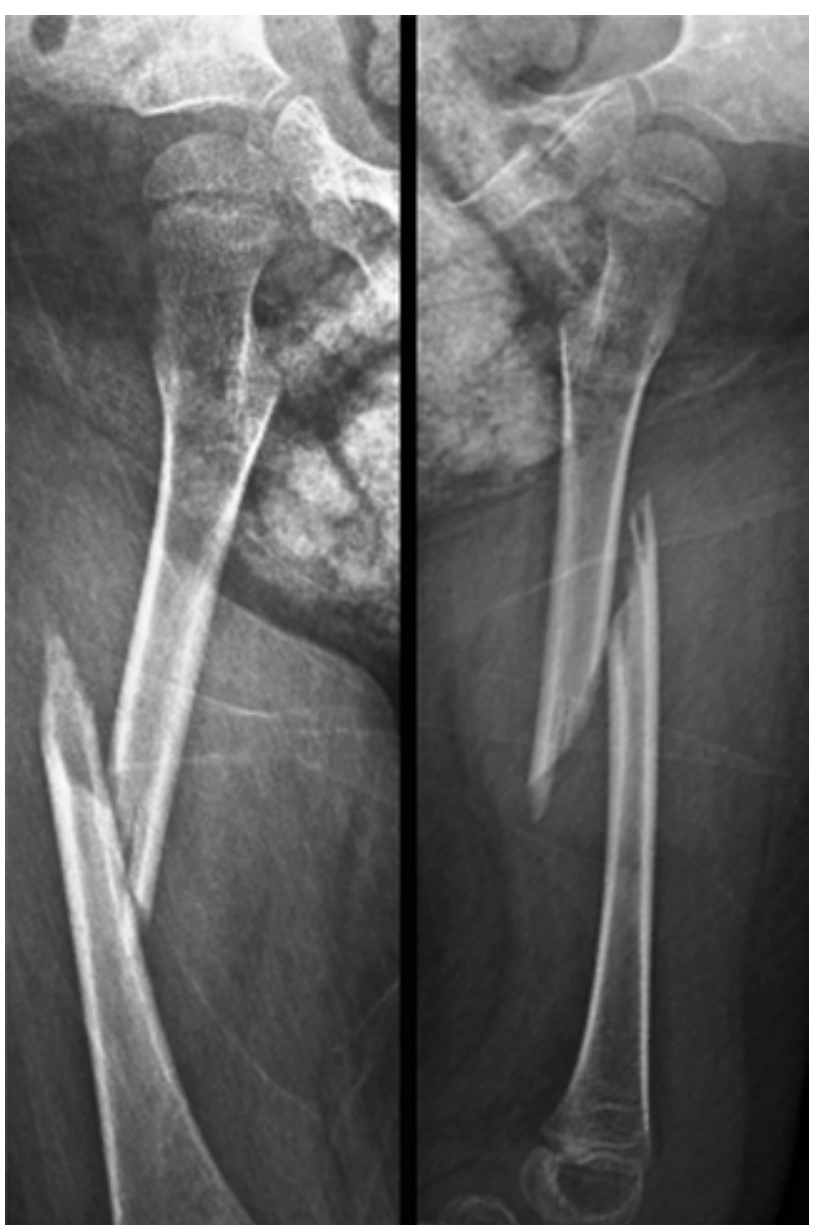

Şekil 3. Femur AP ve lateral grafi.

Femur cisim kırıkları, kırığın yerine göre; subtrokanterik, diyafiziyel ve suprakondiller olarak sınıflandırılabilir. Özelllikle subtrokanterik kırıkların, açısal deformiteleri ve dizilimi kompanse etme kapasitesi sınırlıdır. Bu bölgeye etki eden deforme edici güçlü kas kurvetlerinin varlığı da redüksiyonu zorlaştırır. ${ }^{[13]}$

Kırık paterni stabiliteyi anlamada yardımcı olur. Basit kısa oblik kırıklar boy olarak stabildir. Uzun oblik, uzun spiral ve parçalı kırıklar boy olarak stabil değildir. ${ }^{[19]}$

\section{Tedavi}

Günümüzde, hasta ve hasta yakınları, hastalıklar ve tedavi seçenekleri hakkında bilgiye daha kolay ulaşmaktadırlar. Bu istekler karşısında, doktor da tedavi seçeneklerini iyi bilmeli, cerrahi becerilerinin farkında olmalı ve olası komplikasyonları hasta ve hasta yakınlarına da anlatarak uygun tedaviye karar vermelidir. 


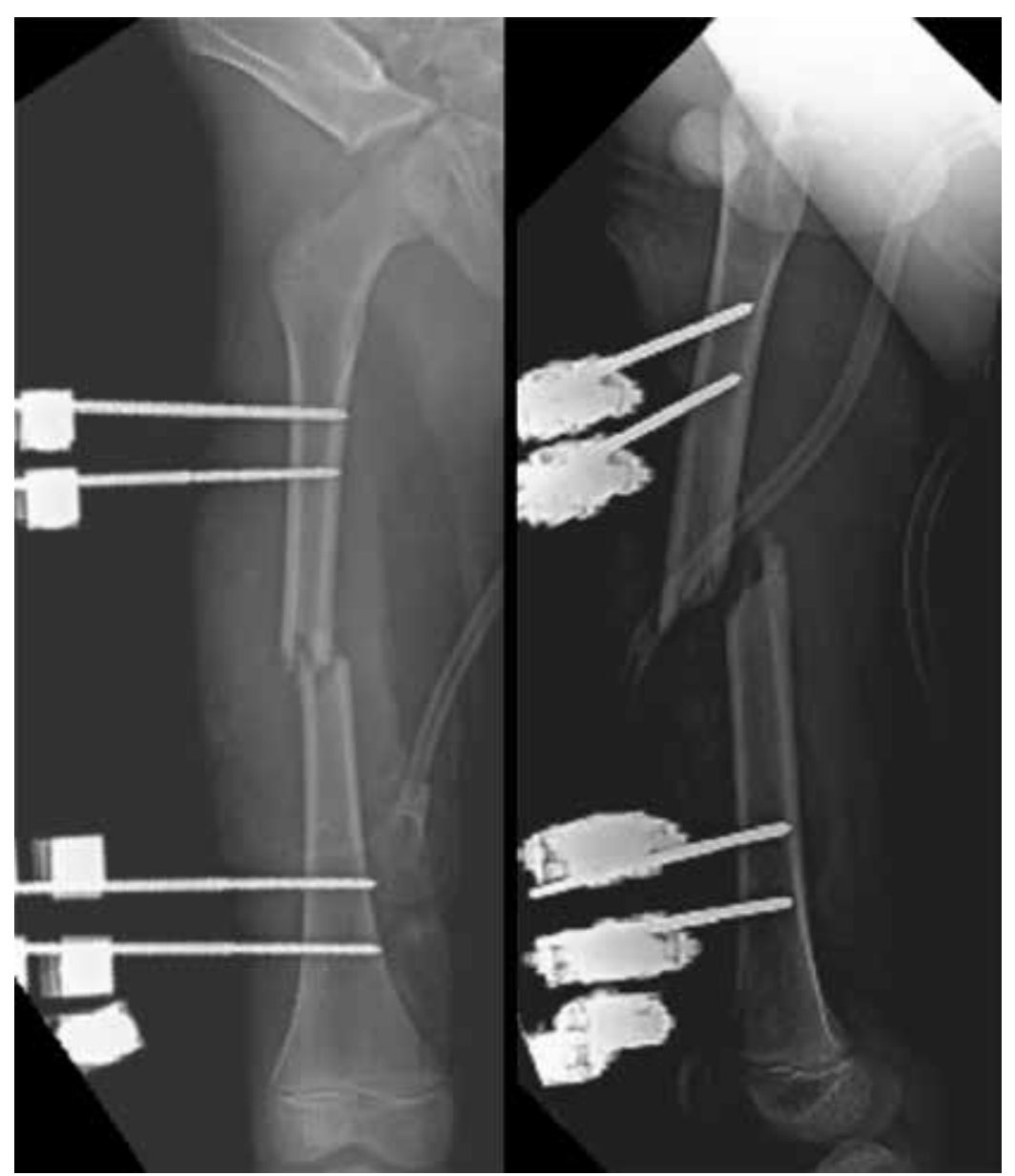

Şekil 4. On yaş erkek açık femur cisim kırığı (eksternal fiksatör).

Günümüzde, pediatrik femur cisim kırıklarının tedavisi, konservatif tedaviden cerrahi tedaviye doğru kaymaktadır. Bu eğilim birçok yayında, kısalan hastane kalış süreleri, azalan yanlış kaynama oranları ve iyi sonuçlarla desteklenmektedir. ${ }^{[20]}$

Pediatrik femur kırığının optimal cerrahi stabilizasyonunun ne zaman yapılacağı üzerinde bir fikir birliği yoktur. ${ }^{[21]}$ Çoklu travması olan hastalar, cerrahi için uygun oluncaya kadar eksternal fiksatör veya traksiyon ile takip edilebilir. Eğer iki hafta içerisinde medikal durumu düzelirse internal tespite geçilebilir. ${ }^{[22]}$ Açık kırıkların tedavisinin zamanlaması da tartışmalıdır, ancak acil debridman sonrası geçici veya kalıcı tespit yapılabilir (Şekil 4). ${ }^{[23]}$

Pediatrik femur kırıklarında kalıcı tedavi planlanırken hastanın yaşı temel alınır. Ancak, iskelet yaşı ile kronolojik yaş arasındaki farklılıklar, hastaların morfolojisi, kilosu ve boyu tedaviyi seçerken göz önünde bulundurulmalıdır.
Altı aylık veya daha küçük çocuklar Pavlik bandaj veya pelvipedal alçı ile tedavi edilebilir. ${ }^{[13,24]}$ Bu yaştaki kırıklar 2-3 hafta gibi kısa zamanda iyileşir ve önemli ölçüde remodele olurlar (Şekil 5).

Altı ay ile beş yaş arasında $2 \mathrm{~cm}$ 'den daha az kısalığı olan çocuklar erken pelvipedal alçı veya traksiyon sonrası yapılan pelvipedal alçı ile tedavi edilebilir (Şekil 6). ${ }^{[11]}$ Kısalığın $2 \mathrm{~cm}$ 'den fazla olduğu kırıklar instabil olarak değerlendirilir. Bu nedenle, 3-10 gün traksiyon-pelvipedal alçı veya plak, eksternal fiksatör gibi alternatif yöntemlerle tedavi edilir. ${ }^{[12]}$ Kısalığın 2 cm'den fazla olması, yumuşak doku hasarı olduğunun ve periostun sıyrıldığının bir göstergesidir; yüksek enerjili travmayı akla getirir. Uzun oblik, uzun spiral ve parçalı kırıklar uzunluk açısından instabildir. ${ }^{[19]}$ Teleskop testi uygulanarak değerlendirme yapılabilir. Bu yaş grubunda, metabolik kemik hastalığı veya multi-travması olanlarda fleksibl intramedüller çivi uygulanabilir (Şekil 7). ${ }^{[10,13]}$ 

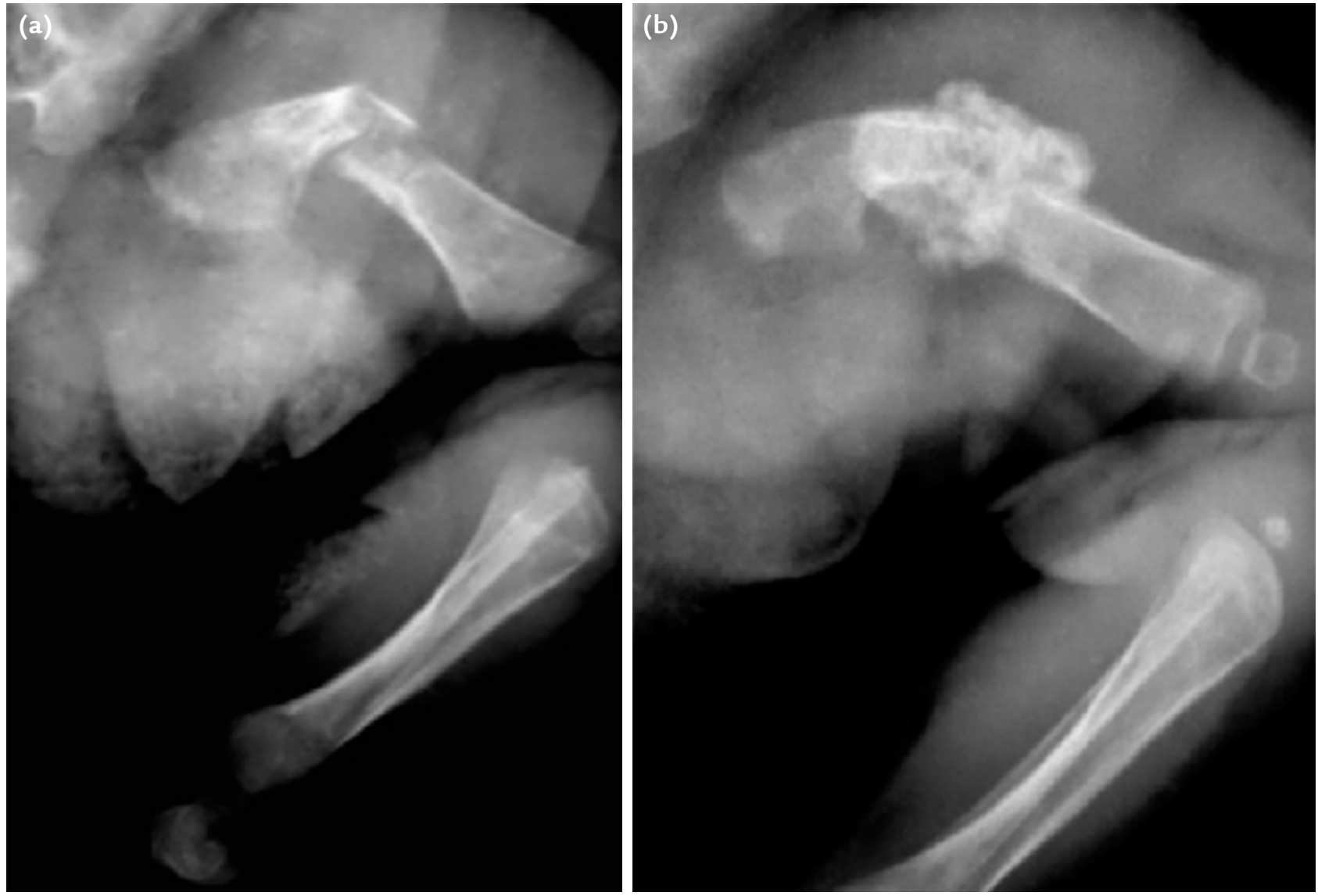

Şekil 5. a, b. Üç haftalık kız çocuğu. Femur cisim kırığı (a); iki hafta sonra görülen kallus dokusu (b).

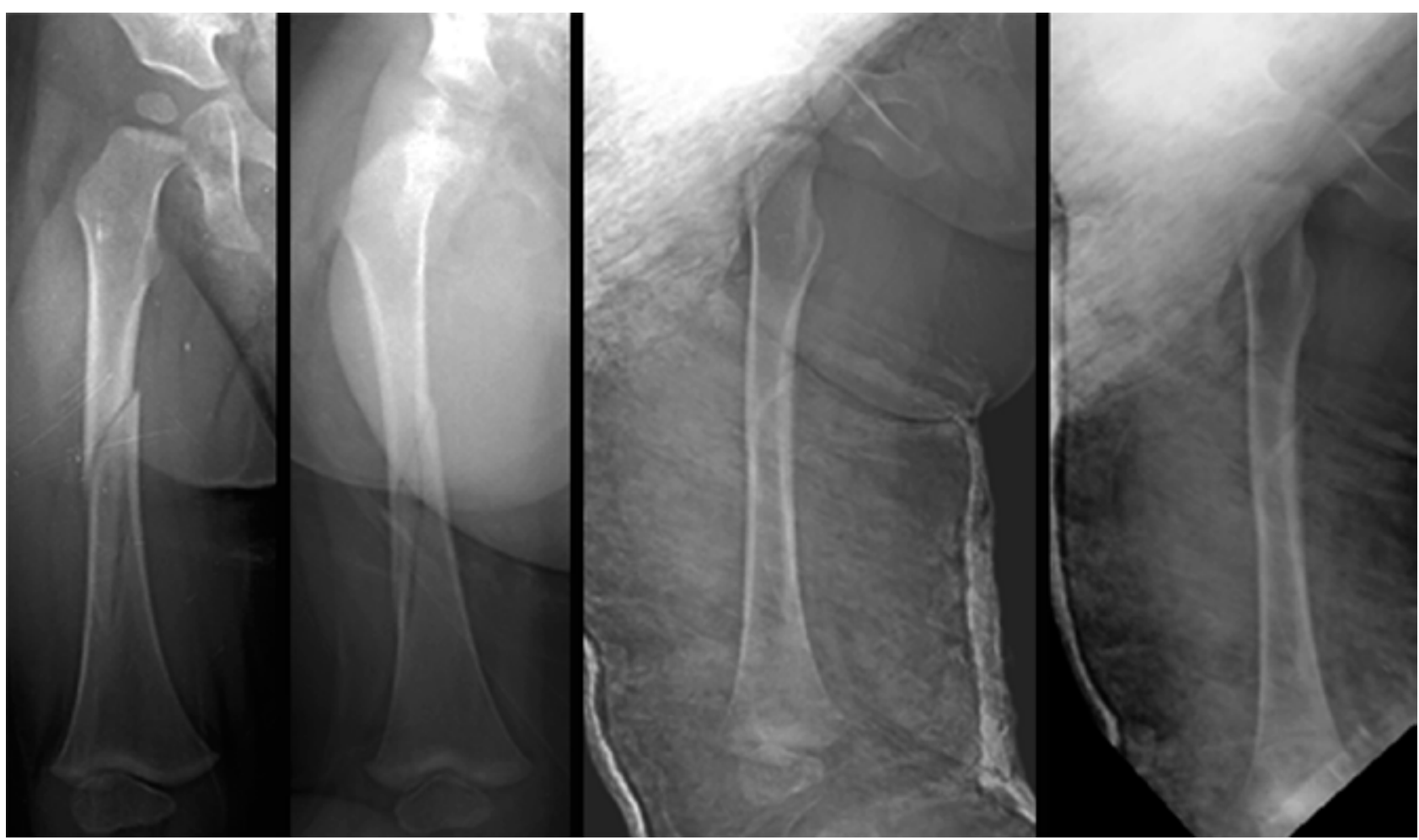

Şekil 6. Dokuz aylık erkek, femur cisim kırı̆̆ı ve pelvipedal alçılama. 


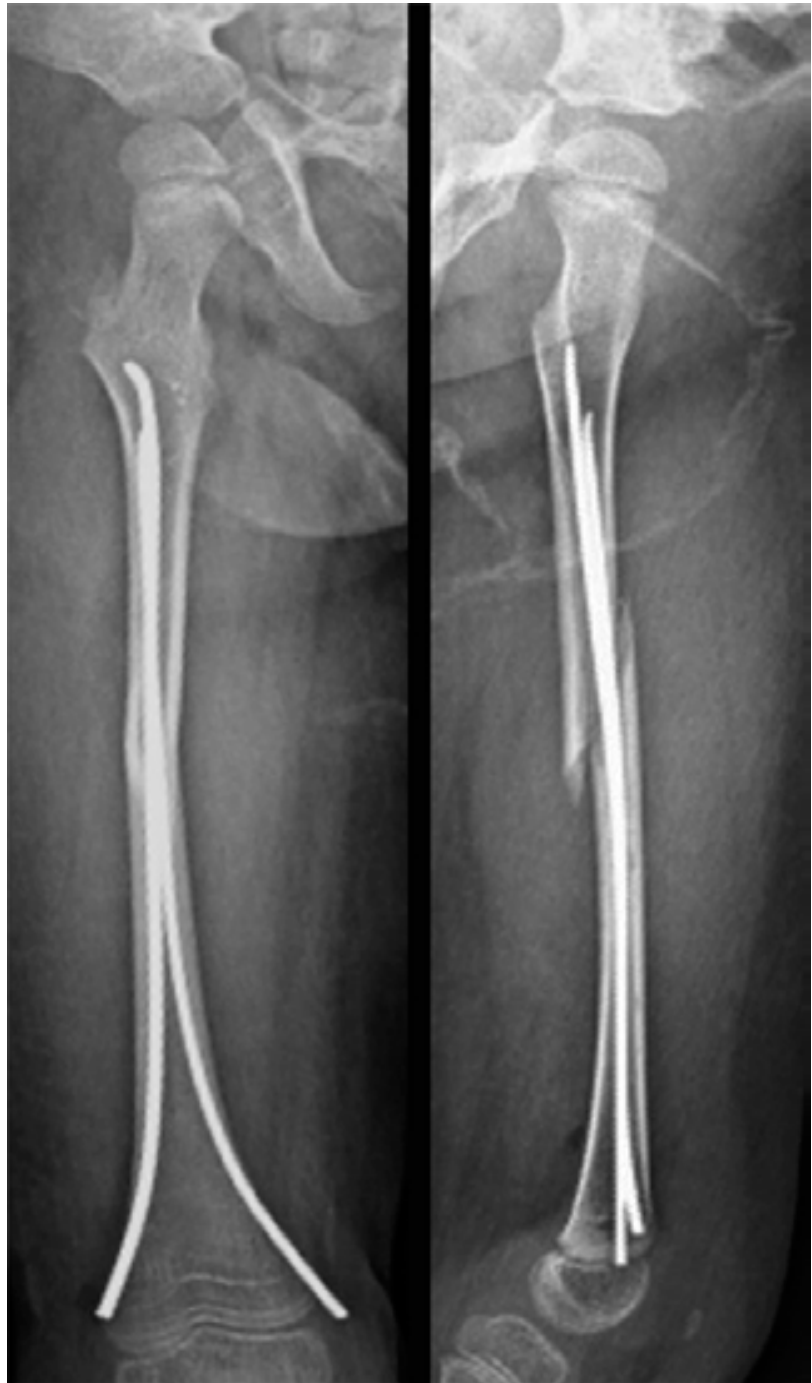

Şekil 7. Altı yaş erkek femur cisim kırığı fleksibl intramedüller çivi.

Beş yaş ile 11 yaş arasındaki femur kırıkları, genellikle fleksibl intramedüller çivi ile tedavi edilir. Fleksibl intramedüller çivi ile tedavi edilen hastalarda, daha az açısal deformite ve daha az uzunluk farkı görülmektedir. ${ }^{[11,13]}$ Hastane yatış süresi kısadır, erken mobilizasyon sağlanır ve komplikasyon oranı traksiyon sonrası yapılan pelvipedal alçı veya eksternal fiksatöre göre daha azdır. Ancak, 49 kilodan ağır olan hastalarda kötü sonuç alma ihtimali fazladır; bu hastalarda plak veya trokanterik girişli intramedüller çivi önerilir. ${ }^{[19,25]}$

On iki yaş ile iskelet matüritesi tamamlanmış hastalarda, femoral kanal genişliği yeterli ise trokanterik girişli intramedüller çivi kullanımı önerilir (Şekil 8, Tablo 1). ${ }^{[26,27]}$ Yetişkin gruptan farklı olarak, pediatrik grupta femur başı avasküler nekrozu gelişme riski

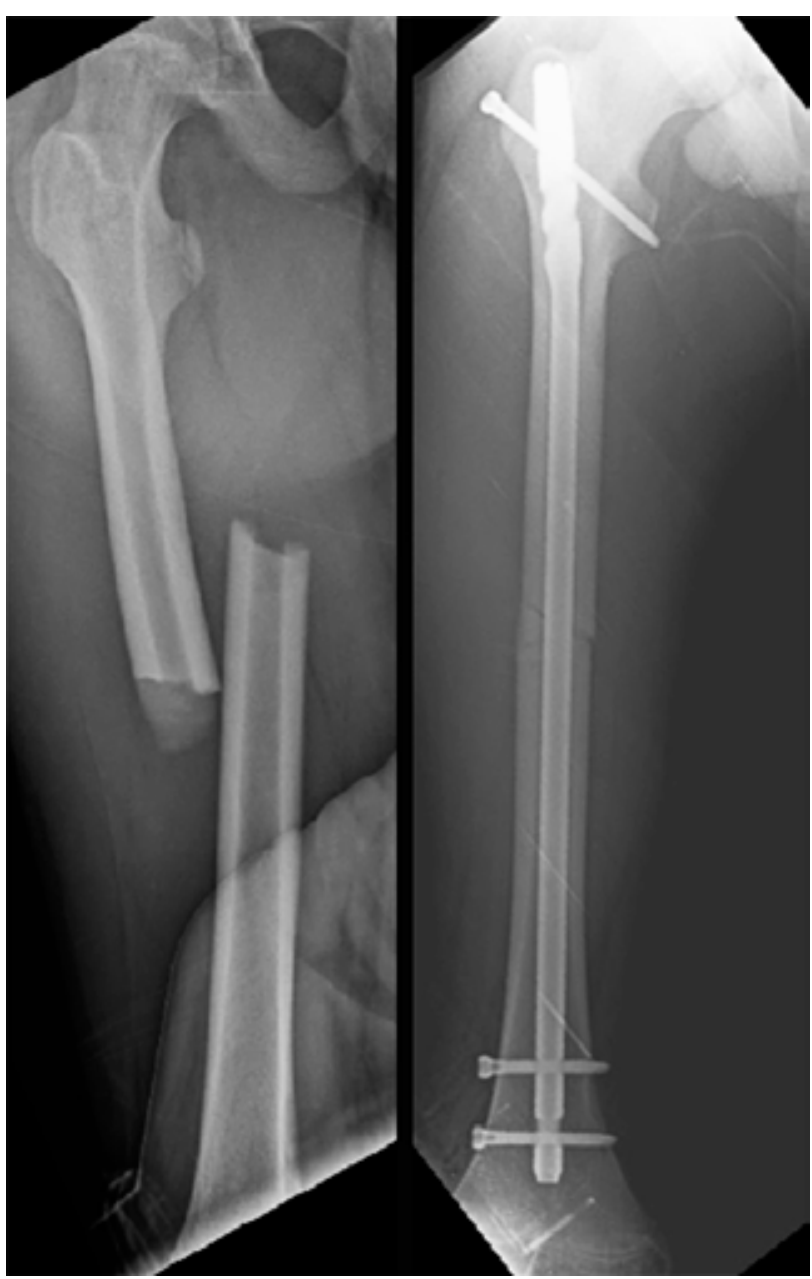

Şekil 8. On dört yaş erkek, femur cisim kırığı ve trokanterik girişli intramedüller çivi.

Tablo 1. Pediatrik femur cisim kırıklarında tedavi seçenekleri

\begin{tabular}{ll}
\hline Yaş & Tedavi seçenekleri \\
\hline $0-6$ ay & Pavlik bandaj, erken pelvipedal alçılama \\
6 ay - 5 yaş & $\begin{array}{l}\text { Erken pelvipedal alçılama, traksiyon-pelvipedal } \\
\text { alçılama }\end{array}$ \\
& Fleksibl intramedüller çivi, eksternal fiksatör \\
& Fleksibl intramedüller çivi, pelvipedal alçılama \\
5-12 yaş & $\begin{array}{l}\text { Trokanterik girişli intramedüller çivi, plak, } \\
\text { eksternal fiksatör }\end{array}$ \\
& $\begin{array}{l}\text { Trokanterik girişli intramedüller çivi, fleksibl } \\
\text { intramedüller çivi }\end{array}$ \\
& Plak, eksternal fiksatör
\end{tabular}

vardır. $\mathrm{Bu}, \% 2$ oranında, çivinin girişi sırasında priformis fossa yakınındaki femur başını besleyen damarların yaralanması sonucu gelişir. Bu nedenle, trokanterik girişli çiviler tercih edilerek bu komplikasyondan kaçınılabilir. ${ }^{[27]}$ 
- İki yaşından küçük çocuklarda $30^{\circ}$ 'ye kadar varus/valgus ve anterior/posterior açılanma,

- Iki ile beş yaş arası $15^{\circ}$ 'ye kadar varus/valgus ve $20^{\circ}$ anterior/posterior açılanma,

- Altı ile on yaş arası $10^{\circ}$ ye kadar varus/valgus ve $15^{\circ}$ anterior/posterior açılanma,

- On bir yaşından sonra ise $5^{\circ}$ ye kadar varus/valgus ve $10^{\circ}$ anterior/posterior açılanma kabul edilebilir değerlerdir. ${ }^{[13]}$

\section{Komplikasyonlar}

Kaynamamaların, artan internal tespit ve yüksek enerjili yaralanmalar sonucunda geliştiği dikkat çekmektedir. Nadir görülmekle birlikte enfeksiyonun, altı yaşından büyük çocuklarda, açık kırıklar sonrasında görülme insidansı artmaktadır. ${ }^{[12,19]}$

Rotasyonel ve açısal malalignment dikkat çeken diğer bir komplikasyondur. İnternal tespit ile bu komplikasyon azalmakta olup, konservatif tedavilerde veya eksternal fiksatör kullanımlarında artmaktadır. ${ }^{[25]}$

Kırık sonrasında, femoral büyüme plaklarında vasküler perfüzyon artar ve bunun sonucunda femoral uzama artışı oluşur. Bu uzama artışı genellikle $1 \mathrm{~cm}$ 'dir. Nadiren $2 \mathrm{~cm}$ 'yi geçer ve bu olay genellikle kırık sonrasındaki ilk iki yıl içinde gerçekleşir. Uzama artışı tedavi şeklinden bağımsız olarak gelişir. Bu nedenle, pelvipedal alçılama yapılırken kırık parçalarının $1 \mathrm{~cm}$ üst üste binmesi önerilir. ${ }^{[12]}$

\section{DISTAL FEMUR KIRIKLARI}

\section{DISTAL FEMORAL METAFIZ KIRIKLARI}

Suprakondiller femur kırıkları, pediatrik femur kırıklarının \%12'sini, tüm pediatrik kırıkların ise \%3'ünü oluşturmaktadır. ${ }^{[12,28]}$

\section{Anatomi}

Femur distalinin etrafında önemli anatomik yapılar yer alır. Mediyal korteksin proksimalinde femoral arter adduktor kanaldan geçerek posterior kompartmana giriş yapar, adduktor hiatustan çıkarken popliteal arter olarak adlandırılır ve popliteal fossaya giriş yapar. Popliteal fossada femur metafizinin posterioru ile popliteal arteri ince bir yağ dokusu ayırır.

Posterior tibial sinir popliteal arterin yanında seyreder. Popliteal fossanın hemen üzerinde siyatik sinirden common peroneal sinir ayrılır ve fossanın lateral kenarı boyunca devam eder.

\section{Yaralanma Mekanizması}

Distal femoral metafiziyel kırıklar genellikle, uyluğa anteriordan veya lateralden gelen direkt travmalar veya yüksekten düşmeler sonucu oluşur. Bir yaşından küçük çocuklarda veya açılanamayan yaralanmalarda, hastaneye geç başvurularda ve ek yaralanmaları olanlarda, çocuk istismarı açısından dikkatli olunmalıdır. ${ }^{[29]}$ Köşe kırıkları, "bucket-handle" lezyonları çocuk istismarı şüphesini güçlendirir. Bunun haricinde, daha büyük çocuklarda da deplase olmayan kırıklar veya stres kırıkları görülebilir. Hasta, lokal ağrı ve hassasiyet tarif eder; radyografide yeni periosteal kemik oluşumu görülür.

Distal femoral metafiz kırıkları; osteogenezis imperfekta, spinal musküler atrofi ve hemofili gibi bazı iskelet sistemi hastalıkları ile beraber de görülebilir. ${ }^{[28]}$

\section{Genel Yaklaşım}

Distal femur metafiz kırıkları genellikle; şişlik, hassasiyet ve deformite ile birlikte görülür. Açık kırık olup olmadığının tespiti için cilt dikkatlice incelenir. Çevrede bulunan nörovasküler yapılar nedeniyle, dikkatlice nabızlara bakılır ve nörolojik muayene yapılır. Doppler ultrasonografi (US) kullanılabilir. ABI'ye bakılır. ${ }^{[14]}$ Ekstremite iskemik ise sirkülasyonu sağlamak amaçlı nazikçe redüksiyon manevrası yapılabilir. Nabız alınamıyor veya zayıf alınıyorsa ileri görüntüleme yöntemlerine geçilir; gerekirse eksplorasyon yapılabilir.

Kırık sonrası ilk birkaç gün, kompartman sendromu açısından hasta takip edilmelidir.

Hastanın ilk müdahalesinin ardından, tüm femuru içine alan, kalça ve diz eklemini gösteren anterior-posterior (AP) ve lateral grafiler çekilmelidir.

\section{Sınıflama}

Sınıflama genellikle kayma miktarına ve parçalanma miktarına göre yapılır.

\section{Tedavi}

\section{Konservatif tedavi}

Kaymamış distal femur metafiz kırıklarında konservatif tedavi uygulanabilir. Özellikle obez çocuklarda, pelvipedal alçı en güvenli yöntemlerden biridir. Kırık yakından takip edilmelidir. ${ }^{[29]}$

Traksiyon sonrası alçı uygulaması, çok kullanılan bir yöntem olmamakla beraber, geçici immobilizasyon ve uzunluğun sağlamasında kullanılabilir. Kalıcı tedaviye karar verme sürecinde zaman kazandırır.

Hastaların alçıda kalış süresi yaşa göre değişir. Çok küçük çocuklarda birkaç hafta iken, daha büyük çocuklarda 6-8 haftaya kadar uzatılabilir. Alçı çıkarıldıktan sonra rehabilitasyon başlar. Hastanın tolere edebildiği kadar yük vermesine izin verilir. Hasta tam gücüne kavuşana kadar koltuk değneği ile mobilizasyonu önerilir. 
Traksiyon ve alçı uygulaması ile tedavi edilen hastalarda en sık görülen komplikasyon, varus deformitesi ve eğer pin kullanılırsa da fizlerin erken kapanmasına bağlı oluşan rekurvatum deformitesidir.

Koopere alçı uygulaması ise diğer bir konservatif yöntemdir. Başlangıçta uygulanan traksiyonu takiben, genel anestezi altında distal femura geniş bir "Steinman pini" yerleştirilir ve pin alçı ile kaplanacak şekilde üzerine sirküler alçı yapılır. ${ }^{[29]}$ Bu sayede varus deformitesi önlenmeye çalışılır.

\section{Cerrahi tedavi}

Kaymış distal femur metafiz kırıklarında cerrahi tedavi gereklidir. Distal parçaya eşlik eden deforme edici kuvvetler, uzunluğu ve dizilimi sağlamada problem yaratmaktadır. Genellikle, distal parça gastrokinemius kasının çekmesi nedeniyle posteriora açılanır. Eğer kırık hattı adduktor magnus kasının yapışma yerinin proksimalinde ise, distal kırık parçası ayrıca varusa gider.

Cerrahi tedavi seçenekleri; eksternal fiksatör, perkütan pin ile tespit ve uzun bacak alçı uygulanması, açık redüksiyon ve internal tespit, plak uygulaması şeklinde sınıflandırılabilir. ${ }^{[29]}$

Politravmalı, açık kırıklı ve yüzen dizlerde, eksternal fiksatör uygulaması başarı ile uygulanır. Pinler lateralden ve fiz hattının en an $1 \mathrm{~cm}$ (tercihen $2 \mathrm{~cm}$ ) proksimalinden uygulanmalıdır. ${ }^{[30]}$ Bu sayede, fizlerin termal hasardan korunması sağlanır. Eğer hasta uyumlu ise, koltuk değneği ile parsiyel yük verilmeye erkenden başlanır. Radyografide kallus görüldükten sonra, yaşa göre 6-12 hafta sonra eksternal fiksatör sonlandırılır. Eksternal fiksatör kullanımı sırasında yaşanması muhtemel komplikasyon, pin dibi enfeksiyonudur. Hasta ve ailesi günlük pin dibi bakımı konusunda bilgilendirilmelidir. Diğer komplikasyonlar; yanlış kaynama ve pin yerinde veya kırık hattında oluşan refraktürdür. ${ }^{[28,31]}$

Kapalı redüksiyon ve perkütan pinleme, kırık hattının metafiz distalinde olduğu seçilmiş hastalarda uygulanan bir yöntemdir. Kapalı redüksiyon sağlandıktan sonra, pinler çapraz yapacak şekilde kırık hattından geçirilir. Distal parçanın çok kısa olduğu kırıklarda, distal femoral fizis kırıklarında olduğu gibi, fiz hattı geçilerek pinleme yapılabilir. Ardından, diz $20-30^{\circ}$ fleksiyonda uzun bacak alçı uygulanır. Dördüncü haftada pinler çıkarılır. Altı ila sekiz haftada da alçı çıkarılır. ${ }^{[29]}$ Bu teknikteki olası komplikasyonlar, mediyalde bulunan femoral damarlara zarar verilmesi ve büyüme plağında meydana gelebilecek büyüme bozukluklarıdır.

Kapalı redüksiyonun başarılı olamadığı veya damar yaralanmasının olduğu kırıklar da açık redüksiyon ve internal tespit ile tedavi edilir. Redüksiyonun sağlanamamasının en önemli nedeni, kırık hattındaki interpoze kaslardır. Eğer damar yaralanması varsa posteromediyal yaklaşım, eğer yoksa direkt lateral yaklaşım kullanılabilir. Kırık redüksiyonu sonrası plak ile tespit edilir. Plak 6-8 ay sonra çıkarııı, ardından hasta 4-6 ay alçı ile takip edilir. ${ }^{[29]}$

Çok parçalı instabil kırıklarda submusküler köprü plaklama yapılabilir. ${ }^{[32,33]}$ Açılan küçük insizyonlardan plak vastus lateralisin altına yerleştirilir. Perkütan vidalar ile kilitli plak sabitlenir. Operasyon sonrası diz hareketlerine başlanır. Erken kallus görülene dek, hasta parmak ucu mobilize olur. Plak 6-8 ay sonra çıkarılır. Geleneksel açık redüksiyona göre daha hızlı kemik iyileşmesi görülür.

Nörovasküler yaralanmanın olmadığı distal femur kırıklarında sonuçlar mükemmele yakındır. Kırık çok hızlı iyileşir ve hastalar kısa sürede yaşamlarına geri dönerler. ${ }^{[29]}$

\section{Komplikasyonlar}

Distal femur metafiz kırkları sonrası en sık karşılaşılan komplikasyon yanlış kaynamadır. Fleksiyon ve ekstansiyon tipi deformitelerin yüksek remodelizasyon kapasitesi vardır. Varus veya valgus deformitelerinde ise remodelizasyon kapasitesi düşüktür. Deformiteye yönelik ek müdahale gerekebilir.

\section{DISTAL FEMORAL FIZIS KIRIKLARI}

Distal femoral fizis kırıkları tüm fiziyel yaralanmaların \%1,4-5,5'ini oluşturur. Tüm çocuk kırıklarının ise \%1'idir. Ancak, bu kırıkların \%40-60'ı ek cerrahi gerektirecek komplikasyonlara neden olur. Anatomik redüksiyon sağlanıp sağlanmadığına bakılmaksızın, hastaların \%35-50'sinde açısal deformite, büyümede bozukluk veya kısalık görülür. ${ }^{[13,34,35]}$

\section{Yaralanma Mekanizması}

Günümüzde distal femoral fizis yaralanmalarının, çoğunlukla 2-11 yaşları arasında trafik kazaları veya spor ile ilgili yaralanmalar sonucunda oluştuğu tespit edilmiştir. ${ }^{[13,35,36]}$ Altta yatan nedenlere bağlı olarak; nöromusküler hastalıklarda, eklem kontraktürleriyle birlikte yetersiz beslenmenin görüldüğü çocuklarda düşük enerjili yaralanmalarla da meydana gelebilir. ${ }^{[37]}$ Dört yaşın altındaki çocuklarda çocuk istismarından şüphelenmek gerekir. ${ }^{[9,13]}$

En sık görülen mekanizma, dize uygulanan varus ve valgus kuwvetleridir. Yetişkinden farklı olarak ligamentöz yapılar fiziyel yapıdan daha güçlüdür. Bükülme (bending) kuvveti sonrasında, bağlarda kopma değil, fiz hattında bir ayrılma meydana gelir. Bükülme kuvveti aynı tarafta gerinim karşı tarafta ise kompresyon 


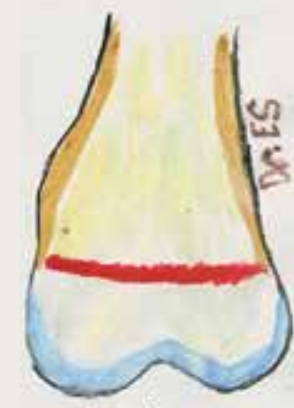

Tip 1

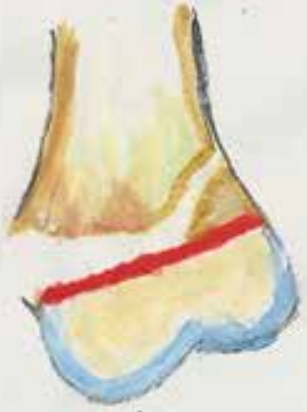

Tip 2

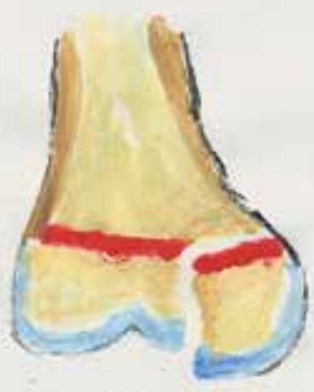

Tip 3

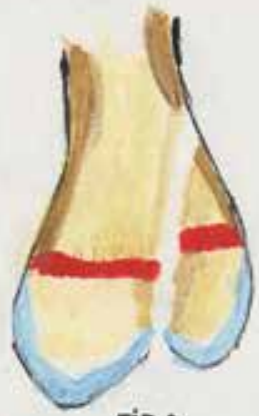

Tip 4

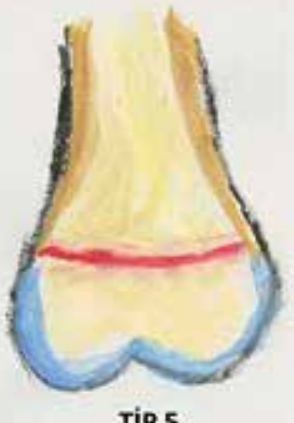

Tip 5

Şekil 9. Salter-Harris sınıflaması.

meydana getirir. Gerilmenin olduğu tarafta, periost ve perikondriyal halkada bozulma meydana gelir. Bunu hipertrofik zondan başlayan irregüler bir kırık hattı takip eder. ${ }^{[29]}$

Salter-Harris Tip 1'de, kırık hattı hipertrofik zonda devam eder, germinatif tabakaya ulaşmadan ekleme paralel seyreder. Salter-Harris Tip 2 kırıkta, kırık hattı femur metafizine doğru uzanır. Kompresyonun olduğu tarafta bir metafiz parçası fiz hattından ayrılmadan kalır (Thurstan-Holland parçası). Salter-Harris Tip 3 ve 4'te kırık hattı tüm fizi geçerek eklem kıkırdağına ulaşır. Tamamen kompresyon kuvvetleri ile oluşan yaralanmalarda ise Salter-Harris Tip 5 kırıklar meydana gelir (Şekil 9). İzole kompresyon yaralanmalarında özellikle, prematür büyüme plağı durması görülür. ${ }^{[13,34,38]}$

\section{Genel Yaklaşım}

Illk olarak kaza veya olay dikkatlice sorgulanmalı, yaralanma mekanizması ögrenilmelidir. Distal femur fizis kırı̆ı olan hastaların muayenesinde; dizde şişlik, diz ekleminde effüzyon, fiz hattında hassasiyet vardır. Kaymış kırıklarda krepitasyon alınabilir; eğer krepitasyon alınamıyor ise, kırık hattına yumuşak doku veya periostun girdiği düşünülür.

ilk olarak AP ve lateral grafiler çekilir. Minimal kaymış kırıkları değerlendirmek için ayrıca oblik grafiler de istenebilir. Eklem kıkırdağına uzanım gösteren kırıkları değerlendirmek için ise MR ve BT istenebilir. SalterHarris Tip 3 kırıklarda, bunlara çapraz bağ yırtıkları da eşlik edebildiğinden dolayı, MR mevcut durum ile ilgili daha iyi bilgi verir.

Sınıflama Salter-Harris sınıflamasına göre yapılır.
Ayrıntılı bir nörovasküler muayene yapılır. Nabız, peroneal sinir, tibialis posterior sinir muayenesi not edilir. $A B I$ ölçümü yapılabilir. Kapiller dolumda gecikme, siyanoz, solukluk, soğukluk olması durumunda, redüksiyon denemesi hemen yapılır. Geri dönüş olmaz ise, arteriyografi veya benzer görüntülenme yöntemlerine geçilir. ${ }^{[39]}$ Takiplerde özellikle, hastalar kompartman sendromu açısından takip edilmelidir.

\section{Tedavi}

\section{Konservatif tedavi}

Kaymamış Salter-Harris Tip 1-2 kırıklar için konservatif tedavi uygulanır. Alçıda kalma süresi hastanın yaşına göre değişiklik gösterir. Kısa boylu, şişman ve uyumsuz hastalar pelvipedal alçı ile takip edilebilir. Hastalar yakından takip edilmeli, bir hafta sonra kontrole çağırılarak radyografileri çekilmelidir. Kaymamış Tip 3-4 kırıklar alçı ile takip edilebilse de, perkütan pinleme ve alçı ile takip önerilir. ${ }^{[13,29]}$

\section{Cerrahi tedavi}

Kaymış kırıklar ve eklem içi kırıklar, perkütan pinleme, uzun bacak alçı veya açık redüksiyon internal tespit ile tedavi edilir.

Kaymış Salter-Harris Tip 1-2 kırıklar ile kaymamış Salter-Harris Tip 3-4 kırıkların, kapalı redüksiyon ve perkütan tespitle tedavi edilmesi önerilir. Redüksiyon sağlandıktan sonra Tip 1 ve küçük metafizer parçanın eşlik ettiği Tip 2 kırıklarda çapraz pinleme önerilir. Yeterli metafizer parçanın bulunduğu Tip 2 kırıklarda ise, kanüllü vida yardımılla tespit yapılabilir. Tip 3 kırıklarda epifız, pin veya kanüllü vida ile tespit edilir. Tip 4 kırıklarda metafiziyel parça, pin veya kanüllü vida ile 
tespit edilir. Eğer yeterli stabilite sağlanamaz ise, epifiz de pin veya vida ile tespit edilebilir. ${ }^{29,34]}$

Kapalı redükte edilemeyen Tip 1-2 kırıklarda açık redüksiyon internal tespit uygulanır. Sağlam periosta zarar vermemek için, epifiz mediyale kaymış ise lateral yaklaşım, epifiz laterale kaymış ise mediyal yaklaşım tercih edilir. Tüm kaymış Tip 3-4 kırıklarda, açık redüksiyon internal tespit gerekir. Artiküler yüzey görülür ve anatomik redüksiyon sağlanır. Bu tip kırıklarda daha büyük insizyonlara ihtiyaç duyulur. Tip 4 kırıklarda hem artiküler yüz hem de metafizer bölge görülmelidir. Redüksiyon sonrası bir veya iki kanüllü vida kullanılmalıdır. Gerekirse epifiz içinde tespit yapılabilir. Operasyon sonrası altı hafta uzun bacak alçı uygulanır; ardından rehabilitasyona başlanır. Radyolojik olarak kırığın iyileştiği görüldükten sonra yük verilmesi önerilir.

\section{Komplikasyonlar}

Takiplerde redüksiyon kaybı gelişebilir. Bu nedenle hastalar, yakından takip edilmelidir. Travma sırasında gelişen bağ yaralanmalarının, kırık iyileştikten sonra da farkına varılabilir. Kırık iyileşmesi sonrası laksitesi devam eden hastalar, tekrar değerlendirilmeli ve takipleri yapılmalıdır. ${ }^{[29]}$

Fizisdeki büyümenin durması veya bozulması sık karşılaşılan bir durumdur. Basener ve ark.'nın yaptığı bir çalışmada, hastaların \%52'sinde fiziste büyümenin bozulduğu tespit edilmiştir. Bu nedenle, hastalar altı aylık aralıklarla takip edilmeli, bacak uzunluk farkı veya açısal deformiteler değerlendirilmelidir. ${ }^{[38]}$

\section{KAYNAKLAR}

1. Sanders JO, Browne RH, Mooney JF, Raney EM, Horn BD, Anderson DJ, Hennrikus WL, Robertson WW. Treatment of femoral fractures in children by pediatric orthopedists: results of a 1998 survey. J Pediatr Orthop 2001;21(4):436-41. Crossref

2. Dodwell E, Wright J, Widmann R, Edobor-Osula F, Pan TJ, Lyman S. Socioeconomic Factors Are Associated With Trends in Treatment of Pediatric Femoral Shaft Fractures, and Subsequent Implant Removal in New York State. J Pediatr Orthop 2016;36(5):459-64. Crossref

3. Rewers A, Hedegaard H, Lezotte D, Meng K, Battan FK, Emery K, Hamman RF. Childhood Femur Fractures, Associated Injuries, and Sociodemographic Risk Factors: A PopulationBased Study. Pediatrics 2005;115:e543-52. Crossref

4. Hedlund $R$, Lindgren $U$. The incidence of femoral shaft fractures in children and adolescents. J Pediatr Orthop 1986;6(1):47-50. Crossref

5. Hinton RY, Lincoln A, Crockett MM, Sponseller P, Smith $G$. Fractures of the femoral shaft in children. Incidence, mechanisms, and sociodemographic risk factors. J Bone Joint Surg Am 1999;81(4):500-9. Crossref

6. Gautier E, Ganz K, N Krügel, Gill T, Ganz R. Anatomy of the medial femoral circumflex artery and its surgical implications. J Bone Joint Surg Br 2000;82(5):679-83. Crossref
7. Chung SM. The arterial supply of the developing proximal end of the human femur. J Bone Joint Surg Am 1976;58(7):96170. Crossref

8. Ostrum RF, Marcantonio A, Marburger R. A critical analysis of the eccentric starting point for trochanteric intramedullary femoral nailing. J Orthop Trauma 2005;19(10):681-6. Crossref

9. Hoytema van Konijnenburg EM, Vrolijk-Bosschaart TF, Bakx R, Van Rijn RR. Paediatric femur fractures at the emergency department: accidental or not? Br J Radiol 2016 89(1061):20150822. Crossref

10. Ortiz EJ, Isler MH, Navia JE, Canosa R. Pathologic fractures in children. Clin Orthop Relat Res 2005;(432):116-26. Crossref

11. Kocher MS, Sink EL, Blasier RD, Luhmann SJ, Mehlman CT, Scher DM, Matheney T, Sanders JO, Watters WC 3rd, Goldberg MJ, Keith MW, Haralson RH 3rd, Turkelson CM, Wies JL, Sluka P, McGowan R; American Academy of Orthopaedic Surgeons.. American Academy of Orthopaedic Surgeons clinical practice guideline on treatment of pediatric diaphyseal femur fracture. J Bone Joint Surg Am 2010;92(8):1790-2. Crossref

12. Shilt J, Li Y. Chapter 14: Fractures of the Femoral Shaft, In: Mencio GA, Swiontkowski MF, editors. Green's Skeletal Trauma in Children, 5th ed. Philadelphia: W. B. Saunders; 2015 pp.365-89.

13. Price $C T$, Herrera-Soto J. Extra-articular injuries of the knee. In: Beaty JH, Kasser JR. Rockwood and Wilkins' Fractures in Children. Philadelphia PA: Walter Klower/Lippincott, William and Wilkins; 2010. pp.842-885.

14. Levy BA, Zlowodzki MP, Graves M, Cole PA. Screening for extermity arterial injury with the arterial pressure index. Am J Emerg Med 2005;23(5):689-95. Crossref

15. Unal VS. Gulcek M, Unveren Z, Karakuyu A, Ucaner A. Blood loss evaluation in children under the age of 11 with femoral shaft fractures patients with isolated versus multiple injuries. J Trauma 2006;60(1):224-226. Crossref

16. Lynch JM, Gardner MJ, Gains B. Hemodynamic significance of pediatric femur fractures. J Pediatr Surg 1996;31(10):135861. Crossref

17. Thompson JD, Buehler KC, Sponseller PD, Gray DW, Black BE, Buckley SL, Griffin PP. Shortening in femoral shaft fractures in children treated with spica cast. Clin Orthop Relat Res 1997;338:74-8. Crossref

18. Dickson KF, Galland MW, Barrack RL, Neitzschman HR, Harris MB, Myers L, Vrahas MS. Magnetic resonance imaging of the knee after ipsilateral femur fracture. J Orthop Trauma 2002;16(8):567-71. Crossref

19. Sink EL, Gralla J, Repine M. Complications of pediatric femur fractures treated with titanium elastic nails: a comparison of fracture types. J Pediatr Orthop 2005;25(5):577-80. Crossref

20. Wright JG. Wang EE, Owen JL, Stephens D, Graham HK, Hanlon M, Nattrass GR, Reynolds RA, Coyte P. Treatments for paediatric femoral fractures: a randomised trial. Lancet 2005;365(9465):1153-8. Crossref

21. Hedequist $D$, Starr AJ, Wilson $P$, Walker J. Early versus delayed stabilization of pediatric femur fractures: analysis of 387 patients. J Orthop Trauma 1999;13(7):490-3. Crossref

22. Della Rocca GJ, Crist BD. External fixation versus conversion to intramedullary nailing for definitive management of closed fractures of the femoral and tibial shaft. J Am Acad Orthop Surg 2006;14(10 Spec No.):S131-5. Crossref

23. Skaggs DL, Friend L, Alman B, Chambers HG, Schmitz M, Leake B, Kay RM, Flynn JM. The effect of surgical delay on acute infection following 554 open fractures in children. J Bone Joint Surg Am 2005;87(1):8-12. Crossref 
24. Podeszwa DA, Mooney JF, Cramer KE, Mendelow MJ. Comparison of Pavlik harness application and immediate spica casting for femur fractures in infants. J Pediatr Orthop 2004;24(5):460-2. Crossref

25. Moroz LA, Launay F, Kocher MS, Newton PO, Frick SL, Sponseller PD, Flynn JM. Titanium elastic nailing of fractures of the femur in children. Predictors of complications and poor outcome. J Bone Joint Surg Br 2006;88-B(10):1361-6. Crossref

26. Kanellopoulos AD, Yiannakopoulos CK, Soucacos PN. Closed, locked intramedullary nailing of pediatric femoral shaft fractures through the tip of the greater trochanter. J Trauma 2006;60(1):217-22; discussion 222-3. Crossref

27. Keeler KA, Dart B, Luhmann SJ, Schoenecker PL, Ortman MR, Dobbs MB, Gordon JE. Antegrade intramedullary nailing of pediatric femoral fractures using an interlocking pediatric femoral nail and a lateral trochanteric entry point. J Pediatr Orthop 2009;29(4):345-51. Crossref

28. Parikh SN, Nathan ST, Priola MJ, Eismann EA. Elastic nailing for pediatric subtrochanteric and supracondylar femur fractures. Clin Orthop Relat Res 2014;472(9):2735-2744. Crossref

29. Zionts LE, Silva M, Gamradt S. Chapter 15: Fractures around the Knee in Children. In: Mencio GA, Swiontkowski MF, editors. Green's Skeletal Trauma in Children, 5th ed. Philadelphia: W. B. Saunders; 2015. pp.390-436.

30. Letts $M$, Vincent $N$, Gouw $G$. The "floating knee" in children. J Bone Joint Surg Br 1986;68-B(3):442-6. Crossref

31. Skaggs DL, Leet Al, Money MD, Shaw BA, Hale JM, Tolo $\mathrm{VT}$. Secondary fractures associated with external fixation in pediatric femur fractures. J Pediatr Orthop 1999;19(5):5826. Crossref
32. Kanlic EM. Anglen JO, Smith DG, Morgan SJ, RF Pesantez. Advantages of submuscular bridge plating for complex pediatric femur fractures. Clin Orthop Relat Res 2004;426:244-51. Crossref

33. Abdelgawad AA, Sieg RN, Laughlin MD, Shunia J, Kanlic EM. Submuscular bridge plating for complex pediatric femur fractures is reliable. Clin Orthop Relat Res 2013;471(9):2797807. Crossref

34. Arkader A, Warner WC, Horn BD, Shaw RN, Wells L. Predicting the outcome of physeal fractures of the distal femur. J Pediatr Orthop 2007;27(6):703-8. Crossref

35. Eid AM, Hafez MA, Traumatic injuries of the distal femoral physis. Retrospective study on 151 cases. Injury 2002;33(3):251-5. Crossref

36. Pennock AT, Ellis HB, Willimon SC, Wyatt C, Broida SE, Dennis MM, Bastrom T. Intra-articular Physeal Fractures of the Distal Femur: A Frequently Missed Diagnosis in Adolescent Athletes. Orthop J Sports Med 2017;5(10):232596711773156. Crossref

37. Riseborough EJ, Barrett IR, Shapiro F. Growth disturbances following distal femoral physeal fracture-separations. J Bone Joint Surg Am 1983;65(7):885-93. Crossref

38. Basener CJ, Mehlman CT, DiPasquale TG. Growth disturbance after distal femoral growth plate fractures in children: a metaanalysis. J Orthop Trauma 2009;23(9):663-7. Crossref

39. Pezeshki Rad M, Ravari H, Bahadori A, Ajami O. Angiographic Findings of Patients with Blunt or Penetrating Extremity Injuries: Focus on Indications and Contraindications. Bull Emerg Trauma 2014;2(1)27-31. 